\title{
Influence of continuous deformations and tremors of rock mass on a building. Case study
}

\author{
Piotr Strzałkowski ${ }^{1, *}$ \\ ${ }^{1}$ Silesian University of Technology, Faculty Geology and Mining, Gliwice, Poland
}

\begin{abstract}
This work presents an exemplary analysis of the influence of mining exploitations on a building. Continuous deformations of the ground surface in the location of the object were considered. Analysis of the impact of tremors of rock mass on the object was performed. The results of calculations as well as the measurements of surface vibrations accelerations were taken into account. The performed analyses show the influence of a fault on increase of vibrations accelerations.
\end{abstract}

Keywords: continuous deformations, mining tremors

\section{Introduction}

Mining is the economy flywheel, which supplies following raw materials: energetic, chemical, metallic and rock. Despite the huge importance of mining, however, there are some negatives of it [1], taking form of its influence of environment, what is mostly associated with so-called mining damage in building facilities [2,3]. This influence shouldn't be exaggerated, because as a result of strict regulations in force in Poland, the necessity of obtaining the consent of the local government administration for the implementation of exploitation plans, damage to buildings is being limited. According to paper [4] they constitute approximately from $1 \%$ to $3 \%$ of the mining costs. The cost of mining damage removal in Germany in 1996 reached around 350 million DM while the extraction equed 39 million $\mathrm{Mg}$ [5]. Among negative forms of influence of mining on buildings there are [2,3]: continuous deformations, discontinuous deformations and tremors of rock mass. The predictions of mining influence on buildings performed routinely should be taking into account all geological factors which can influence the size and deformation distribution. There are many factors, the most significant of them are: exploitations performed previously, hydrogeological conditions and tectonic disturbances. Especially tectonic faults are a common reason of increased values of deformation indices, and even discontinuous deformations. They also influence the increase of values

* Corresponding author: piotr.strzalkowski@pols.p1 
of vibrations accelerations of mining ground surface. An example of this kind of influence of the fault zone is presented in this work.

\section{Analysis of mining and geological conditions}

\subsection{Lithology and stratigraphy}

The rock mass located in the area of the building consists of layers from following periods:

- Quaternary,

- Neogene,

- Carboniferous.

The overburden consists of quaternary and tertiary layers (Neogene). Carboniferous layers consist mainly of Pleistocene layers, developed as grey and yellow-grey clays stone, sands and fluvioglacial gravels.

Carboniferous layers consist of:

- orzeskie layers - westfal B - group of seams 300

- rudzkie layers - westfal A - group of seams 400

- siodłowe layers - namber B + C - group of seams 500 .

\subsection{Tectonics}

The tectonic fault named Fault $\mathrm{V}$ is in the area of the building. It runs from north-east towards south-west direction. The throw slip in the south-eastern direction equals $70 \mathrm{~m}$. The fault outcrop on the carbonic roof runs in the distance of around $150 \mathrm{~m}$ in the northwestern direction from the building, what is presented in the fig.1.

\subsection{Mining exploitations which were performed}

The table 1, shown below, presents basic information about exploitations performed since 2005. Values of deformation indices in the location of the building were calculated.

Table 1. Basic information about exploitations performed since 2005

\begin{tabular}{|c|c|c|c|c|c|c|c|c|c|}
\hline $\begin{array}{c}\text { coal } \\
\text { seam }\end{array}$ & wall & $\begin{array}{c}\text { beginning } \\
\text { of extrac- } \\
\text { tion }\end{array}$ & $\begin{array}{c}\text { ending } \\
\text { of extrac- } \\
\text { tion }\end{array}$ & $\begin{array}{c}\text { thickness } \\
\text { of coal } \\
\text { seam } \\
{[\mathrm{m}]}\end{array}$ & $\begin{array}{c}\text { angle } \\
\text { of } \\
\text { slope }\end{array}$ & $\begin{array}{c}\text { depth } \\
{[\mathrm{m}]}\end{array}$ & $\begin{array}{c}\text { distance } \\
{[\mathrm{km}]}\end{array}$ & $\begin{array}{c}\text { direc- } \\
\text { tion }\end{array}$ & a \\
\hline 4132 & sc._5 & $\begin{array}{c}30-09- \\
2005\end{array}$ & $\begin{array}{c}30-06- \\
2006\end{array}$ & 1,8 & 7 & 690 & 0,46 & $\mathrm{~W}$ & 0,6 \\
\hline 4132 & sc._4 & $\begin{array}{c}30-10- \\
2006\end{array}$ & $\begin{array}{c}30-09- \\
2007\end{array}$ & 1,8 & 7 & 660 & 0,20 & $\mathrm{~W}$ & 0,6 \\
\hline 5022 & sc.22 & $\begin{array}{c}01-01- \\
2007\end{array}$ & $\begin{array}{c}01-01- \\
2008\end{array}$ & 3,0 & 10 & 885 & 0,49 & $\mathrm{E}$ & 0,8 \\
\hline 5022 & sc.33 & $\begin{array}{c}15-07- \\
2016\end{array}$ & $\begin{array}{c}01-04- \\
2017\end{array}$ & 3,4 & 10 & 920 & 0,51 & SE & 0,8 \\
\hline 504 & sc_1J & $\begin{array}{c}02-11- \\
2011\end{array}$ & $\begin{array}{c}01-03- \\
2012\end{array}$ & 2,4 & 8 & 875 & 0,49 & $\mathrm{E}$ & 0,8 \\
\hline 504 & sc_2J & $\begin{array}{c}01-04- \\
2014\end{array}$ & $\begin{array}{c}01-04- \\
2015\end{array}$ & 2,5 & 10 & 910 & 0,49 & $\mathrm{E}$ & 0,8 \\
\hline 506 & sc_1 & $01-04-$ & $01-06-$ & 2,4 & 5 & 890 & 0,53 & $\mathrm{E}$ & 0,8 \\
\hline
\end{tabular}




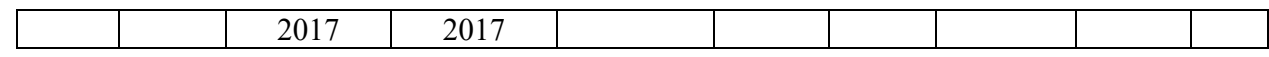

The table gives information about: time of exploitation performed with particular walls, thickness of coal seam or layer, angle (slope) of the seam, depth on which the seam lay in the area of the wall, distance from the building, direction of walls location in relation to the building, value of coefficient of exploitation, the way of roof control. Figure 1 shows the location of performed exploitations in relation to the building, which is marked as number „15”.

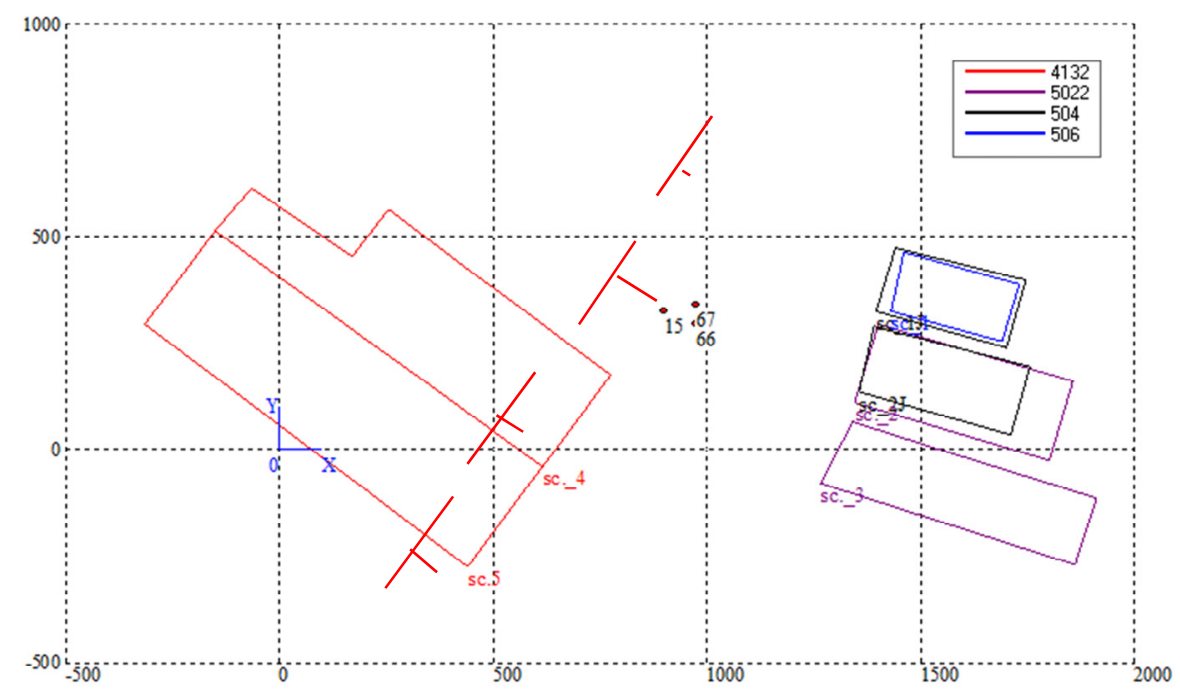

Fig. 1. Scheme of location of selected walls in relation to the object (15) and observing points 66 and 67 in the local coordinate system.

\section{Information about the building}

The object is a residential building, single-family house with two floors. It was built in 1975 in traditional brick technology. It was protected from exploitation influences by anchoring. The inclination of the building as a result of the impact of exploitations performed in previous years was visible. Many horizontal and diagonal cracks on internal and external walls have been observed since 2015. These cracks occurred mostly where the walls were weakened, so that near doors and windows (fig. 2). No slots in walls have been observed. No linear discontinuous deformations were observed in the area of the building. 


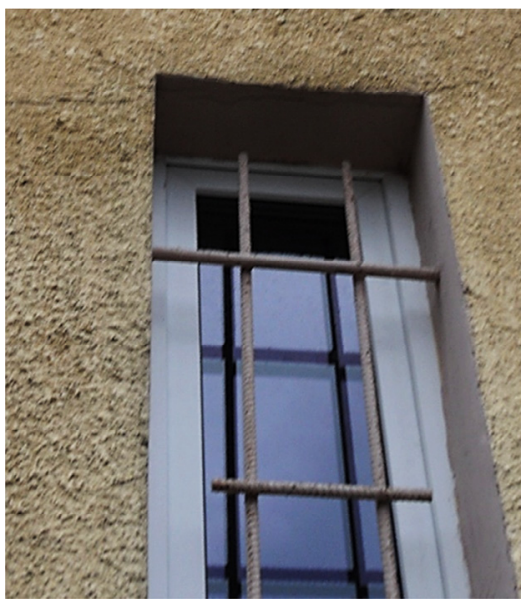

Fig. 2. Cracked outer wall

\section{Influence of performed exploitations on the building}

\subsection{Influence of performed exploitations on the building in the light of the results of calculations}

Computer programme DEFK-Win [6,7], based on W. Budryk's - S. Knothe's theory [8] was used for calculations of values of deformation indices. The accuracy of the theory has been discussed in paper [9].

The following values of parameters were adopted for calculations on the basis of experience of the coal mine:

- coefficient of roof control $-\boldsymbol{a}=\mathbf{0 , 8}$ for caving, $\boldsymbol{a}=\mathbf{0 , 6}$ for caving with locating fly ashes,

- tangent of an angle of main influences $-\operatorname{tg} \boldsymbol{\beta}=\mathbf{2}$

- coefficient deciding of values of displacements and horizontal deformations $\boldsymbol{B}=\mathbf{0 , 3 2}$

Exploitations performed since 30.09.2005 were taken into account for calculations.

Results of calculations of values of deformation indices are presented in table 2, where:

- mining subsidence $-\boldsymbol{w}$,

- maximal tilts $-\boldsymbol{T}_{\max }$,

- maximal horizontal deformation $-\boldsymbol{E}_{\max }$,

- maximal vertical curvature $-\boldsymbol{K}_{\max }$.

Table 2. Calculated values of deformation indices

\begin{tabular}{|c|c|c|c|c|c|}
\hline Seam & Wall & $\begin{array}{c}\boldsymbol{w} \\
{[\mathbf{m m}]}\end{array}$ & $\begin{array}{c}\boldsymbol{T}_{\max } \\
{[\mathbf{m m} / \mathbf{m}]}\end{array}$ & $\begin{array}{c}\boldsymbol{E}_{\max } \\
{[\mathbf{m m}]}\end{array}$ & $\begin{array}{c}\boldsymbol{K}_{\max } \\
{[\mathbf{1} / \mathbf{k m}]}\end{array}$ \\
\hline $\mathbf{4 1 3 2}$ & sc._5 & -0.1 & 0.00 & 0.01 & 0.000 \\
\hline $\mathbf{4 1 3 2}$ & sc._4 & -19.3 & 0.35 & 0.55 & -0.005 \\
\hline $\mathbf{5 0 2} / \mathbf{2}$ & sc._2 & -1.5 & 0.03 & 0.07 & 0.000 \\
\hline $\mathbf{5 0 2} / \mathbf{2}$ & sc._3 & -0.6 & 0.01 & 0.03 & 0.000 \\
\hline $\mathbf{5 0 4}$ & sc_1J & -1.4 & 0.03 & 0.06 & 0.000 \\
\hline $\mathbf{5 0 4}$ & sc_2J & -1.9 & 0.03 & 0.07 & 0.000 \\
\hline $\mathbf{5 0 6}$ & sc_1 & -0.7 & 0.01 & 0.03 & 0.000 \\
\hline \multicolumn{2}{|c|}{ Sum } & -25.5 & 0.30 & 0.66 & -0.006 \\
\hline
\end{tabular}




\subsection{Impact of performed exploitations on the surface in the area of the building in the light of geodetic survey.}

A measuring line, consisting of observing points of numbers from 62 to 67 was set along the street in the area of the building. Observing points number 66 and 67 are located nearest the building, in the distance of around $60 \mathrm{~m}$. Surveys were performed at different intervals since 2007 till 2017.

The course of subsidence of observing points in time is presented in fig. 3, and the increases of subsidence are shown in fig. 4. As the figures show, in time until September 2009 subsidence of observing points, taking values of $86 \mathrm{~mm}$ and $85 \mathrm{~mm}$, occurred. Next, the subsidence showed small increases - both negative and positive, what testifies about lack of subsidence. The increases of subsidence of values $21 \mathrm{~mm}$ and $27 \mathrm{~mm}$ occurred only between September 2011 and January 2012. After January 2012 the increases of subsidence (alternately positive and negative) took the values of measurement accuracy. According to this, it can be assumed that the area of the object was influenced by subsidence caused by mining exploitations latest until January 2012.

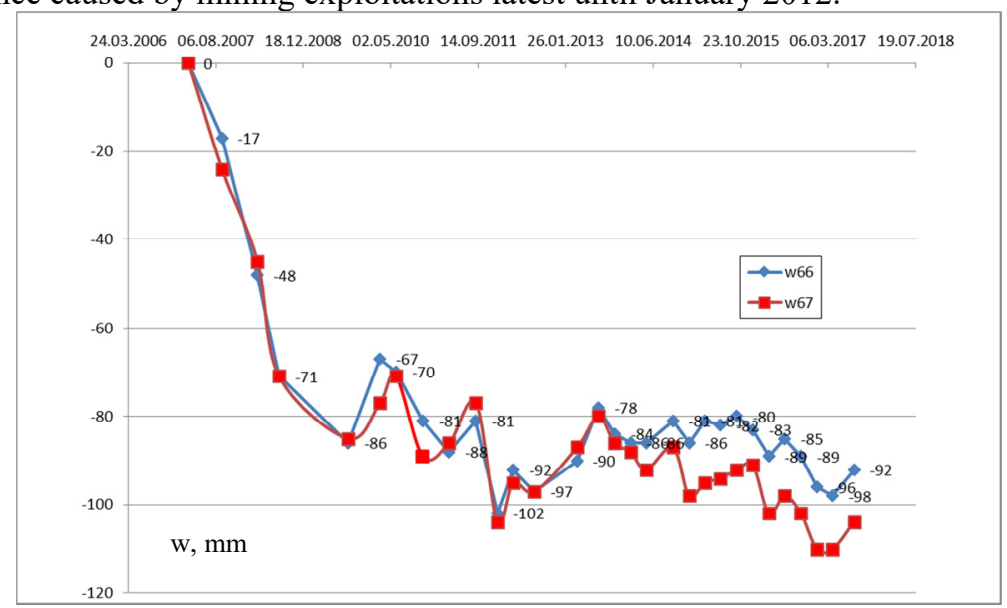

Fig. 3. The course of subsidence of observing points 66 and 67 over time.

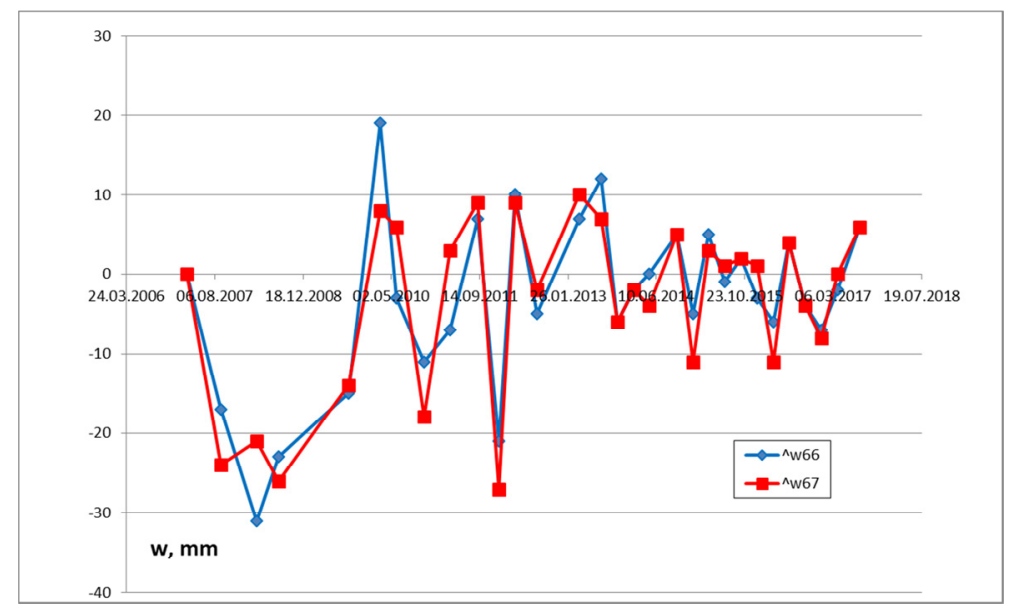

Fig. 4. The course of increase of subsidence of observing points 66 and 67 between surveys. 


\section{Influence of tremors on the object}

The measuring station of the mine records the coordinates of epicentres of tremors and the values of their epicentral energies. Values of vibrations accelerations in the considered place are calculated with usage of the formula of G. Mutke [2]:

$$
a=\left[1,33 \cdot 10^{-3} \cdot(\log E)^{2,66}-0,089\right] \cdot\left[1,53 \cdot R^{0,155} \cdot \exp (-0,065 \cdot R)+0,014\right]
$$

where :

$$
\begin{aligned}
& a \text { - acceleration of vibrations, } \mathrm{mm} / \mathrm{s}^{2} \\
& R=\sqrt{D^{2}+0,5^{2}} \\
& D \text { - epicentral distance, } \mathrm{km} \\
& E \text { - energy of the tremor, } \mathrm{J}
\end{aligned}
$$

This formula allows calculating the value of accelerations of carboniferous rocks. In order to obtain the surface acceleration, the value obtained from the formula should be multiplied by the so-called amplification factor.

In the light of the results of calculations, no tremor caused accelerations higher (or even equal) $250 \mathrm{~mm} / \mathrm{s}^{2}$ in the location of the building. The mine set a measuring point in the distance of around $180 \mathrm{~m}$ from the object. The highest values of accelerations of vibrations registered since 2015 (over $250 \mathrm{~mm} / \mathrm{s}^{2}$ ) are presented in the table 3 . This table also shows values of calculated maximal accelerations and the duration of an intense phase of accelerations of vibrations $t_{\mathrm{Ha}}$. As it can be noticed, the highest registered value was 629 $\mathrm{mm} / \mathrm{s}^{2}$. Values of calculated accelerations for all tremors were lower than measured ones. It is interesting that the tremor which occurred on 02.01.2017 had similar epicentre coordinates and energy to the tremor which occurred on 27.01.2017, and these tremors caused significantly different accelerations of vibrations. The mine rejects the possibility of having made a measurement mistake. These results, so different from expected, were most probably caused by occurrence of the fault zone in the area of the building. The influence of tectonic faults on seismic activity of the rock mass was a subject of many studies $[10,11,12,13,14]$. A wide overview can be found in the work [15]. The author shows two types of seismic phenomenon. First of them are the occurrences directly related to mining works, which characterise with low epicentral energies. Epicentres of these tremors occur in the area of mining extraction. The second type is related to impact of fault zone by running an exploitation in its neighbourhood. Thus, the combined effect of mining and tectonic factors takes place. Tremors like that characterise with higher energies and their epicentres occur in the area of fault zone. Works like [10] confirm this. Similar cases can be found in foreign literature for example the work [11] shows the case where two tremors have occurred in the gold ore mine in South Africa. The epicentres were located at the depth of around $2 \mathrm{~km}$ in the distance of $700 \mathrm{~m}$ from each other. These tremors have been caused by the mining exploitation and the influence of the fault zone. The influence of tectonics of the deposit on damage of buildings as a result of highly energetic tremor is presented in work [12]. The work presents correlations between accelerations and speeds of vibrations in the location of damaged buildings and distance from fault zone.

It is confirmed by the results of analyses presented in the paper [14], which describes the occurrence of very high amplitudes of accelerations of vibrations in the measuring station in the area of the fault zone. Authors expressed their opinion, that a significant 
reason for this, was directionality of radiation. It was concluded that tremors characterising with similar energy and distance from measuring station, can cause different amplitudes of vibrations accelerations of the ground surface.

GSI scales are being constantly developed and actualized [16]. Regarding the scale

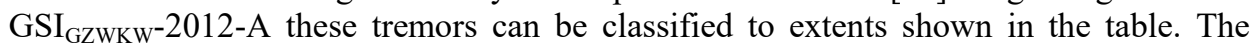
tremor which caused the highest value of accelerations can be classified to extent II. Due to small distance from the measuring station to the object it can be assumed that the values of vibrations accelerations could have been higher than the calculated ones, also in the location of the building. Therefore there are justified assumptions that the building could have been exposed to maximal accelerations of around $600 \mathrm{~mm} / \mathrm{s}^{2}$, which can be classified to extent II in GSI $\mathrm{GZWKW}$-2012-A scale.

The locations of measuring station and the object have been marked in the figure 5 (small red marks). Also tremors epicentres, data about which can be found in table 4, have been marked. Diameter of the circle represents energy of the tremor. Additionally, for easier distinction, the tremor of energy $4.00 \mathrm{E}+09 \mathrm{~J}$ has been marked with yellow. Epicentres of other tremors were marked with blue colour.

Table 4. Juxtaposition of data concerning tremors, which have caused the highest values of accelerations in the location of measuring station.

\begin{tabular}{|c|c|c|c|c|c|c|c|c|}
\hline Date & $\begin{array}{c}\mathbf{E} \\
{[\mathbf{J}]}\end{array}$ & $\begin{array}{c}\mathbf{X} \\
{[\mathbf{m}]}\end{array}$ & $\begin{array}{c}\mathbf{Y} \\
{[\mathbf{m}]}\end{array}$ & $\begin{array}{c}\mathbf{D} \\
{[\mathbf{m}]}\end{array}$ & $\begin{array}{c}\text { PGA } \\
\mathbf{s u r v e y} \\
{\left[\mathbf{m m} / \mathbf{s}^{2}\right]}\end{array}$ & $\begin{array}{c}\text { calculated } \\
\mathbf{P G A} \\
{\left[\mathbf{m m} / \mathbf{s}^{2}\right]}\end{array}$ & $\begin{array}{c}\mathbf{t}_{\text {Ha }}[\mathbf{s}] \\
\text { extent } \\
\mathbf{G S I}\end{array}$ \\
\hline 18.04 .2015 & $4.00 \mathrm{E}+09$ & 20830 & -3000 & 2455 & 258 & 230 & 3,90 & I \\
\hline 05.08 .2016 & $4.00 \mathrm{E}+06$ & 18963 & -2122 & 395 & 459 & 151 & 1,54 & I \\
\hline 02.01 .2017 & $8.00 \mathrm{E}+06$ & 19350 & -2790 & 1096 & $\mathbf{6 2 9}$ & 142 & 1,66 & II \\
\hline 27.01 .2017 & $8.00 \mathrm{E}+06$ & 19170 & -2900 & 1070 & $\mathbf{3 0 0}$ & 143 & 1,55 & I \\
\hline 21.02 .2017 & $2.00 \mathrm{E}+06$ & 19180 & -2830 & 1017 & 313 & 95 & 1,78 & I \\
\hline 14.03 .2017 & $2.00 \mathrm{E}+06$ & 18460 & -2310 & 331 & 310 & 121 & 1,72 & I \\
\hline
\end{tabular}

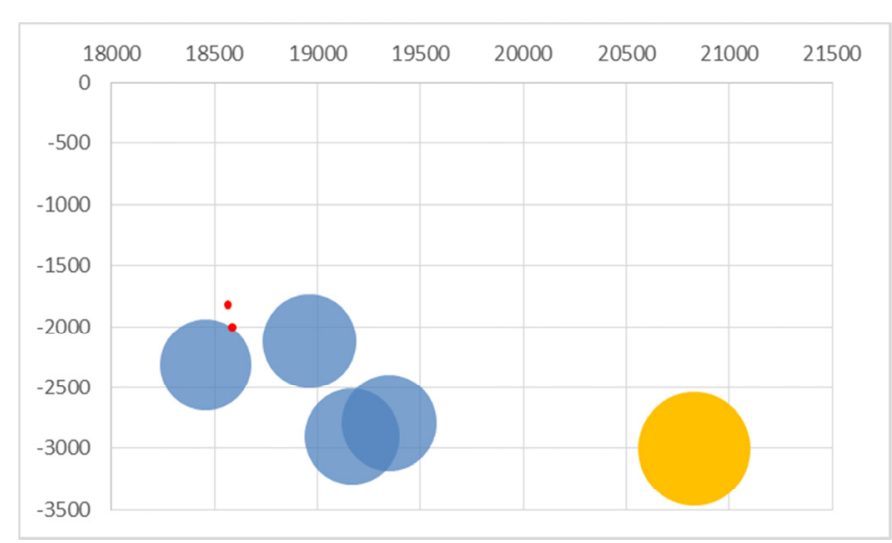

Fig. 5. Location of epicentres of tremors, data about which can be found in table 4 (local coordinate system).

\section{Summary and conclusions}

Analyses of: mining and geological conditions, results of calculations of values of deformation indices and results of surveys and also impact of the tremors on the surface, performed in this work allow us to conclude: 
1. Continuous deformations of the mining area, which developed as a result of exploitations performed in recent years (since 2005) were minor and fit in category I of the mining area. Results of calculations broadly correlate with results of geodetic surveys, which confirm that the surface was not recently influenced by any subsidence. In some cases, however, this compatibility does not occur in tectonically disturbed zone. This is why having access to results of geodetic surveys, which can verify and complete results of calculations, is very important.

2. Analysis of results of calculations and surveys of vibrations accelerations, caused by rock mass tremors, implies as influence of the fault on increase of values of vibrations accelerations of mining ground surface. Formula, which was used, refers to tectonically undisturbed rock mass, which is the reason for observing higher values of vibrations accelerations than calculated ones and even lack of their negative influence on the object. So that also results of surveys of vibrations accelerations proved to be essential for an objective assessment of the impact of mining exploitations on the surface.

3. Mining and geological conditions of the area, including tectonical disturbances, should be considered while assessing the impact of mining works on buildings, since they can influence the size and distribution of deformations, but also they can increase the values of vibrations accelerations on the surface.

\section{References}

1. F.G. Bell, T.R. Stacey, D.D. Genske: Mining subsidence and its effect on the environment: some differing examples. Environmental Geology. 40 (1-2) December (2000).

2. J. Kwiatek (red.): Building facilities in mining areas. Publishing House of GIG, Katowice (1997) (in Polish)

3. P. Strzałkowski: Outline of protection of mining areas. Publisher of the Silesian Technical University, Gliwice (2010) (in Polish).

4. O. Kaszowska: Costs of removing damages in buildings located in mining areas. Przegląd Górniczy no. 4 (2005) (in Polish).

5. A. Sroka: Dynamics of mining exploitation from the point of view of mining damage. The Publishing House of the Mineral and Energy Economy Research Institute of the Polish Academy of Sciences, Kraków (1999). (in Polish).

6. R. Ścigała: Computer aided prediction of rock mass and land surfaces deformation caused by underground mining exploitation. Publisher of the Silesian Technical University. Gliwice (2008)

7. R. Ścigała: The identification of parameters of theories used for prognoses of post mining deformations by means of present software. -Archives of Mining Science. vol. 58 iss. 4. (2013)

8. S. Knothe: Forecasting the impact of mining exploitations. 'Śląsk' Publishing House. Katowice (1984) (in Polish)

9. J. Orwat, R. Mielimąka: The comparison of measured deformation indicators of mining area with theoretical values calculated using Knothe's formulas.: International conference of numerical analysis and applied mathematics 2015. ICNAAM 2015, Rhodes, AIP Publishing, (2016).

10. J. Dubiński, K. Stec: Relationship between focal mechanism parameters of mine tremors and local strata tectonics. In: Dynamic rock mass response to mining. The South African Institute of Mining and Metallurgy, Johannesburg (2001).

11. G.F. Hofmann, L.J. Scheepers: Simulating fault slip areas of mining induced seismic tremors using static boundary element numerical modelling. Journal of Mining 
Technology. Transactions of the Institutions of Mining and Metallurgy: Section A. Volume 120, Issue 1 (2011)

12. E. Pilecka, R. Szermer - Zaucha : Analysis of the impact of hight - Energy tremor from 29 January 2015 in "Rydułtowy - Anna" coal mine and local tectonics on mining damage in building. Przegląd Górniczy no. 10 (2015) (in Polish).

13. E. Pilecka, K. Stec: Analysis of relation between highly energetic seismicity and gravimetric and magnetic anomalies in the area Upper Silesian Coal Basin. Workshop 2003 from series 'Natural dangers in mining'. (2003) (in Polish).

14. K. Stec, S. Denysenko: Characteristics of tremors of the rock mass observed in the Kłodnicki fault zone- Katowice - Panewniki. Workshop 2003 from series 'Natural dangers in mining'. (2003) (in Polish).

15. K. Stec: Seismic activity of the Upper Silesian Coal Basin - 30 years of the continued seismic observations by Upper Silesian Regional Seismic Network. Workshop 2007 from series 'Natural dangers in mining'. (2007) (in Polish).

16. J. Dubiński, G. Mutke: Mining GSI-GZW Intensity Scale to assess the effects of mining tremors in the Upper Silesian Coal Basin on buildings and people. Scientific Works of GIG, Mining and Environment, Special Edition GIG Quarterly, Katowice (2007) (in Polish) 